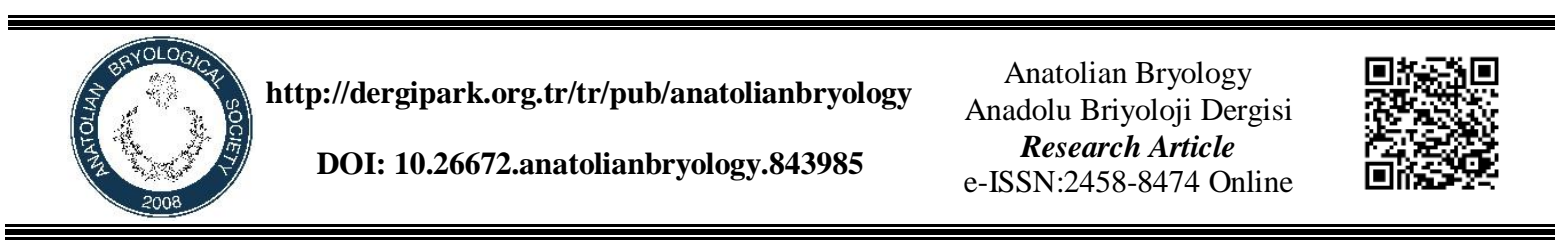

\title{
The Mosses of Ankara University Beşevler 10. Yıl Campus Area (Ankara-Turkey)
}

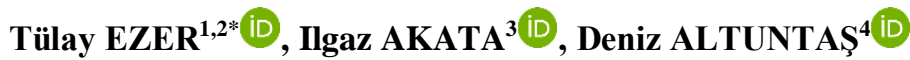 \\ ${ }^{1}$ Niğde Ömer Halisdemir University, Faculty of Science, Department of Biology, Niğde, TURKEY. \\ ${ }^{2}$ Niğde Ömer Halisdemir University, Faculty of Architecture, Department of Landscape Architecture, \\ Niğde, TURKEY. \\ ${ }^{3}$ Ankara University, Faculty of Science, Department of Biology, Ankara, TURKEY. \\ ${ }^{4}$ Ankara University, Graduate School of Natural and Applied Sciences, Ankara, TURKEY
}

\begin{tabular}{lll}
\hline Received: 20 December 2020 & Revised: 15 January 2020 & Accepted: 26 January 2021
\end{tabular}

\begin{abstract}
The present study is based on moss specimens collected from several urban habitats in Ankara University Beşevler 10. Yıl Campus in the year 2019. As a result of identifications of 94 bryophyte specimens collected from the campus area, a total of 28 species belonging to 7 families and 17 genera were determined. Six of them are new record for B7 grid-square. Pottiaceae ( 9 species) and Orthotrichaceae (6 species) are the two largest families in the campus area.
\end{abstract}

Keywords: Biodiversity, Campus, Flora, Mosses.

\section{Ankara Üniversitesi Beşevler 10. Yıl Kampüs Alanı Karayosunları (Ankara- Türkiye)}

Öz

Bu çalışma, 2019 yılında Ankara Üniversitesi Beşevler 10. Y1l Kampüsü’ndeki çeşitli kentsel habitatlardan toplanan karayosunu örneklerine dayanmaktadır. Kampüs alanından toplanan 94 briyofit örneğinin teşhis çalışmaları sonucunda 7 familya ve 17 cinse ait toplam 28 tür tespit edilmiştir. Bunlardan altısı B7 karesi için yeni kayıttır. Pottiaceae ( 9 tür) ve Orthotrichaceae (6 tür), kampüs alanındaki en büyük iki familyadır.

Anahtar kelimeler: Biyoçeşitlilik, Kampüs, Flora, Karayosunları.

\footnotetext{
* Corresponding author: tuezer@gmail.com; tezer@ohu.edu.tr

(C) 2021 All rights reserved / Tüm hakları saklıdır.

To cite this article: Ezer T., Akata I., Altuntaş D., 2021. The Mosses of Ankara University Beşevler 10. Yll Campus Area (Ankara-Turkey). Anatolian Bryology. 7:1, 17-22.

(c) (1) () 9 This work is licensed under a Creative Commons Attribution-Non Commercial 4.0 International License.
} 


\section{Introduction}

Bryophytes have a wide geographical distribution in the world from the poles to the equator and spread almost everywhere where water and moisture are present (Shaw, 2001). Nevertheless, they have been ignored by many botanists because of their primitive structures and small sizes. Turkey is one of the richest countries among the European and Asian countries in bryo-floristic diversity. A total of \pm 1042 bryophyte taxa have been determined from Turkey so far. Among them, \pm 843 are mosses, \pm 195 are liverworts and \pm 4 are hornworts (Özdemir and Batan, 2014; Batan et al., 2014, 2016, 2019; Ezer, 2016; Erdağ and Kürschner, 2017; Yücel and Ezer, 2018; Ursavaş and Işın, 2019; Kürschner and Frey, 2020; Erata and Batan, 2020).

Urban areas have many ecological factors that differ from each other. Urban areas that have many microhabitats provide suitable shelters for small size plants like mosses that are widely adapted to such areas. Therefore, mosses of the urban areas form one of the primary members of the city ecosystems and vegetation (Sabovljevic and Grdovic, 2009).

The campus areas of universities have the characteristics of natural laboratories especially for applied sciences and important biodiversity. Especially, campus areas of universities with a deep-rooted and established structure can be considered as areas where biodiversity is protected. In this context, many floristic studies have been carried out to reveal the plant biodiversity of campus areas in Turkey (Alataş et al., 2011; Erata et al., 2017; Abay, 2018; Akata et al., 2019a; Başköse et al., 2020).

The present study was aimed to explore the moss flora in the urban area of Ankara University Beşevler 10. Yil campus (formerly known as Tandoğan Campus).

\section{Materials and Methods \\ 2.1. Study area}

Ankara University Beşevler 10. Y1l Campus, which is formerly known as Tandoğan Campus, is situated in Beşevler neighborhood of Çankaya district, at an elevation between 850 and 870 meters above the sea level (Akata et al., 2019a). Geographically, it is located between the parallels $39.936800^{\circ} \mathrm{N}$ in the south and $39.937350^{\circ} \mathrm{N}$ in the north, and the meridians $32.826330^{\circ} \mathrm{E}$ in the west and $32.835720^{\circ}$ $\mathrm{E}$ in the east (Figure 1).

The climate type of the study area is semi-arid subMediterranean, with a severe frost period in winter (Akman, 2011).

The campus covers a total surface area of approximately 20 hectares and contains 166 fungi, 28 lichens, and 445 vascular plant species (Akata et al., 2019a,b; 2020; Altuntaş et al., 2019; Başköse et al., 2020; Halıcı and Akata, 2020). The study area falls within the square of B7 according to Henderson's (1961) grid square system (Figure 2).

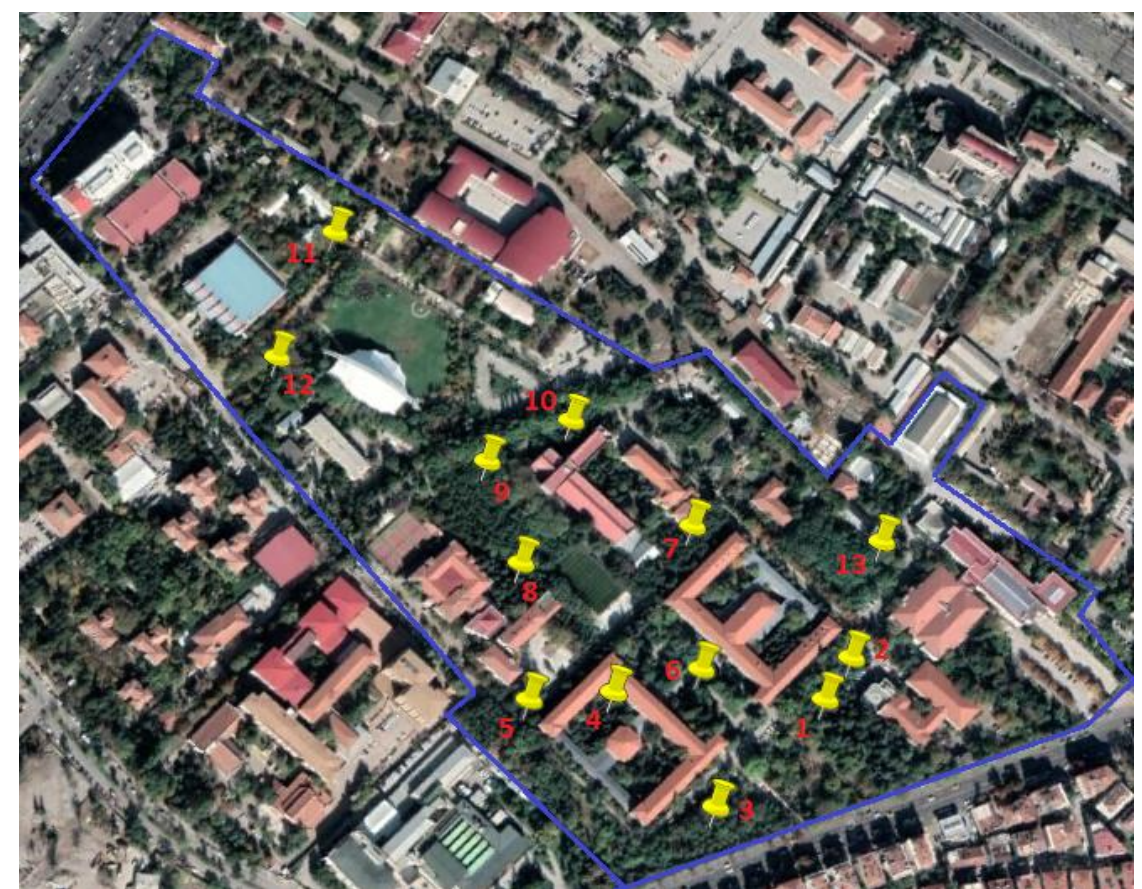

Figure 1. Ankara University Beşevler 10. Y1l Campus area and the points of study localities (developed from Google Earth) 


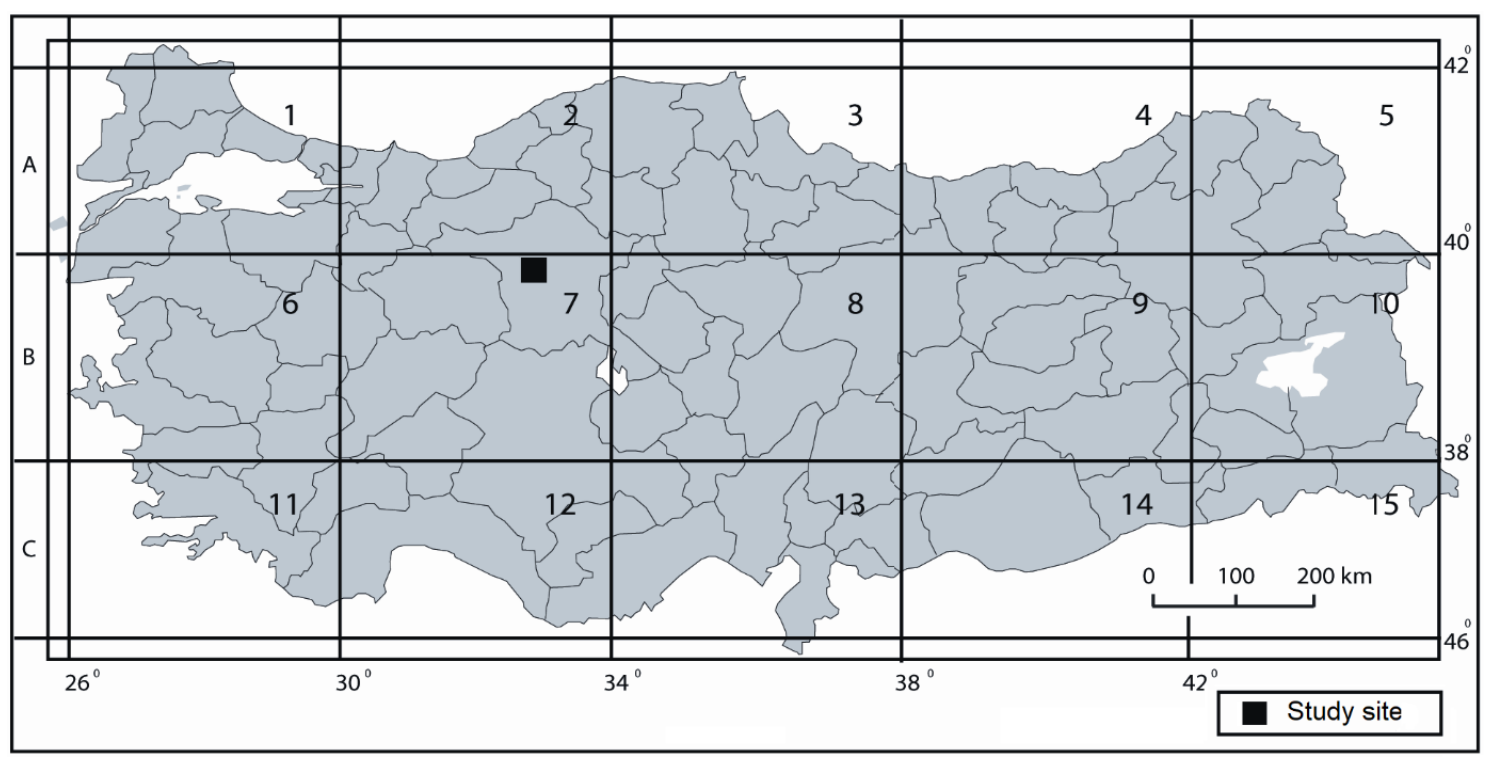

Figure 2. The location of the study site according to the grid system of Turkey (Henderson, 1961)

\subsection{Data source}

The moss specimens, materials of the present study, were collected from various localities, habitats, and substrates in Ankara University Beşevler 10. Y1l Campus area in the year 2019 (Table 1).

Table 1. Localities (L.N.: locality number).

\begin{tabular}{|c|c|c|c|}
\hline L.N. & $\begin{array}{l}\text { Location } \\
\end{array}$ & L.N. & \begin{tabular}{|l} 
Location \\
\end{tabular} \\
\hline 1 & Rectorate building and its surroundings 1 & 8 & $\begin{array}{l}\text { Faculty of Science D Block front garden } \\
1\end{array}$ \\
\hline 2 & Rectorate building and its surroundings 2 & 9 & $\begin{array}{l}\text { Faculty of Science D Block front garden } \\
2\end{array}$ \\
\hline 3 & $\begin{array}{l}\text { Faculty of Science B Block and its } \\
\text { surroundings } 1\end{array}$ & 10 & $\begin{array}{l}\text { Faculty of Science } \mathrm{C} \text { and } \mathrm{F} \text { Blocks } \\
\text { surroundings }\end{array}$ \\
\hline 4 & $\begin{array}{l}\text { Faculty of Science B Block and its } \\
\text { surroundings } 2\end{array}$ & 11 & Olympic swimming pool surroundings \\
\hline 5 & $\begin{array}{l}\text { Faculty of Science D Block and its } \\
\text { surroundings }\end{array}$ & 12 & Recreation area \\
\hline 6 & $\begin{array}{l}\text { The between A and B Blocks of Faculty } \\
\text { of Science }\end{array}$ & 13 & Science Faculty A Block surroundings \\
\hline 7 & Back of Faculty of Science A Block & & \\
\hline
\end{tabular}

The collected moss specimens were identified using relevant literatures (various flora and revisional studies) (Zander, 1993; Greven, 1995; 2003; Muñoz, 1999; Cortini Pedrotti, 2001, 2006; Heyn and Herrnstadt, 2004; Smith, 2004). Voucher specimens are deposited into the Herbaria of Ankara University and Niğde Ömer Halisdemir University. The latest taxonomic status of the moss taxa in Turkey were determined according to the recent literature (Erdağ and Kürschner, 2017; Ros et al., 2013; Hodgetts et al., 2020). Nomenclature of the floristic list was arranged according to Hodgetts et al. (2020).

\section{Results and Discussion}

As a result of identification studies of bryophyte specimens, a total of 28 species, belonging to 7 families and 17 genera were determined (Table 2). 
Table 2. Floristic list (*: new records for B7, r: rock, s: soil, t: tree).

\begin{tabular}{|c|c|c|c|c|c|c|}
\hline \multirow[t]{2}{*}{ Families } & \multirow[t]{2}{*}{ Genera } & \multirow[t]{2}{*}{ Species } & \multirow[t]{2}{*}{ L.N. } & \multicolumn{3}{|c|}{ Substrate } \\
\hline & & & & $\mathbf{r}$ & $\mathbf{s}$ & $\mathbf{t}$ \\
\hline \multicolumn{7}{|l|}{ BRYOPSIDA } \\
\hline Funariaceae & Funaria & Funaria hygrometrica Hedw. & 5,12 & + & + & \\
\hline \multirow[t]{9}{*}{ Pottiaceae } & Barbula & Barbula unguiculata Hedw. & $3,4,10$ & & + & \\
\hline & Gymnostomum & *Gymnostomum aeruginosum $\mathrm{Sm}$. & 6,12 & & + & \\
\hline & Pseudocrossidium & $\begin{array}{l}\text { Pseudocrossidium hornschuchianum } \\
\text { (Schultz) R.H.Zander }\end{array}$ & 6 & & + & \\
\hline & \multirow[t]{3}{*}{ Syntrichia } & Syntrichia princeps (De Not.) Mitt. & 1,3 & & + & \\
\hline & & $\begin{array}{l}\text { Syntrichia ruralis (Hedw.) F.Weber } \\
\text { \& D.Mohr }\end{array}$ & $1,3,9$ & & + & \\
\hline & & $\begin{array}{l}\text { *Syntrichia virescens (De Not.) } \\
\text { Ochyra }\end{array}$ & 3 & & & + \\
\hline & \multirow[t]{3}{*}{ Tortula } & Tortula inermis (Brid.) Mont. & 4,6 & & + & \\
\hline & & Tortula muralis Hedw. & $2,3,5,11$ & + & & \\
\hline & & Tortula subulata Hedw. & 1,3 & & + & \\
\hline \multirow[t]{2}{*}{ Grimmiaceae } & Grimmia & Grimmia pulvinata (Hedw.) Sm. & $1,3,5,12$ & + & & \\
\hline & Schistidium & $\begin{array}{l}\text { Schistidium apocarpum (Hedw.) } \\
\text { Bruch \& Schimp. }\end{array}$ & $1,2,6$ & + & & \\
\hline \multirow[t]{3}{*}{ Bryaceae } & Bryum & Bryum argenteum Hedw. & $5,8,13$ & + & + & \\
\hline & Gemmabryum & $\begin{array}{l}\text { Gemmabryum caespiticium (Hedw.) } \\
\text { J.R.Spence }\end{array}$ & 3,4 & & + & \\
\hline & Rosulabryum & $\begin{array}{l}\text { Rosulabryum capillare (Hedw.) } \\
\text { J.R.Spence }\end{array}$ & $1,2,4,5,10$ & + & + & \\
\hline \multirow[t]{6}{*}{ Orthotrichaceae } & \multirow[t]{6}{*}{ Orthotrichum } & Orthotrichum anomalum Hedw. & 4,6 & + & & \\
\hline & & Orthotrichum diaphanum Brid. & $1,2,3,6,7$ & & & + \\
\hline & & Orthotrichum pallens Bruch ex Brid. & 6,7 & & & + \\
\hline & & *Orthotrichum patens Bruch ex Brid. & $1,3,6$ & & & + \\
\hline & & $\begin{array}{l}\text { Orthotrichum stramineum Hornsch. } \\
\text { ex Brid. }\end{array}$ & 7 & & & + \\
\hline & & $\begin{array}{l}\text { *Orthotrichum tenellum Bruch ex } \\
\text { Brid. }\end{array}$ & 1,3 & & & + \\
\hline \multirow[t]{2}{*}{ Amblystegiaceae } & Amblystegium & $\begin{array}{l}\text { Amblystegium serpens } \quad \text { (Hedw.) } \\
\text { Schimp. }\end{array}$ & 1,2 & & + & \\
\hline & Pseudoamblystegium & $\begin{array}{l}\text { *Pseudoamblystegium subtile } \\
\text { (Hedw.) Vanderp. \& Hedenäs }\end{array}$ & 9,10 & & & + \\
\hline \multirow[t]{5}{*}{ Brachytheciaceae } & Brachytheciastrum & $\begin{array}{l}\text { Brachytheciastrum velutinum } \\
\text { (Hedw.) Ignatov \& Huttunen }\end{array}$ & 7,9 & & & + \\
\hline & \multirow[t]{3}{*}{ Brachythecium } & $\begin{array}{l}\text { Brachythecium glareosum (Bruch ex } \\
\text { Spruce) Schimp. }\end{array}$ & 6 & & + & \\
\hline & & $\begin{array}{l}\text { *Brachythecium mildeanum } \\
\text { (Schimp.) Schimp. }\end{array}$ & $1,2,6$ & & + & \\
\hline & & $\begin{array}{l}\text { Brachythecium rutabulum (Hedw.) } \\
\text { Schimp. }\end{array}$ & 6 & & + & \\
\hline & Oxyrrhynchium & $\begin{array}{l}\text { Oxyrrhynchium hians (Hedw.) } \\
\text { Loeske }\end{array}$ & 3,6 & + & + & \\
\hline
\end{tabular}

The acrocarpous moss family Pottiaceae is the most species-rich family with 9 species, while Orthotrichaceae (6 species) and Brachytheciaceae ( 5 species) are the other common families of mosses in the campus area. Pottiaceae, contains many drought-tolerant species, which is the richest and the most prevalent moss family both in the study area and in Turkey. Therefore, it was not surprising that Pottiaceae is the most species-rich family with nine species in the campus area.

The acrocarpous moss genus Orthotrichum, which has generally epiphytic members, is the most species-rich genus with 6 species and, abundant on the trunks of Pinaceae and Fagaceae members in the Ankara University Beşevler 10. Yıl Campus area. 
The genera Tortula and Brachythecium are represented by 3 taxa in this study. Six species are new to B7 square in the grid system of Turkey adopted by Henderson (1961).

The relatively high moss diversity (28 species) in the study area where is just 20 hectares showed that the campus areas are well-protected areas, although under the anthropogenic pressure. Because, such urban areas like campus areas have many microhabitats provide suitable shelters for mosses which are primitive and small size plants.

The results of the present study will contribute to the Ankara province, B7 square and bryoflora of Turkey.

Acknowledgments: The authors are indebted for financial support to the Ankara University, Research Project Units (Project Number: 18B0430001).

Note: This study was presented as a poster presentation at the EurasianBioChem 2020 (19-20 March 2020, Ankara, Turkey) congress.

\section{References}

Abay G. 2018. The Bryophyte Flora of Recep Tayyip Erdoğan University, Zihni Derin Campus (RizeTurkey). Anatolian Bryology. $4: 2,72-18$.

Akata I. Altuntaş D. Kabaktepe Ş. 2019a. Fungi Determined In Ankara University Tandoğan Campus Area (Ankara-Turkey). Trakya University Journal of Natural Sciences. 20:1, 47-55.

Akata I. Büyük İ. Altuntaş D. Sesli E. 2019 b. Calocybe persicolor, A New Record for the Turkish Mycota. Gazi University Journal of Science. 32:4, 1097-1103.

Akata I. Altuntaş D. Şahin E. 2020. Callistosporium Singer, a New Genus Record for Turkish Mycobiota. Trakya University Journal of Natural Sciences. 21:1, 33-37.

Akman Y. 2011. İklim ve Biyoiklim (Biyoiklim Metodları ve Türkiye İklimleri). Palme Yayıncilık. Ankara.

Alataş M. Ören M. Uyar G. 2011. The bryophyte flora in campus center of Zonguldak Karaelmas University. Bartın Orman Fakültesi Dergisi. 13:20, 51-58.

Altuntaş D. Sesli E. Büyük I. Akata I. 2019. Inocybe mytiliodora: A new record for Turkey. Kastamonu Üniversitesi Orman Fakültesi Dergisi. 19:3, 284-289.

Başköse İ. Körüklü S.T. Yaprak A.E. 2020. The Plant Biodiversity of Ankara University 10. yıl (Beşevler) campus. Biological Diversity and Conservation. 13:3, 217-231.

Batan N. Özcan O. Özdemir T. 2014. New Bryophyte Records from Turkey and Southwest Asia. Telopea. 17, 337-346.

Batan N. Özen Ö. Alataş M. Özdemir T. 2016. Hygrohypnum ochraceum (Bryophyta), new to Turkey and Southwest Asia. Phytologia Balcanica. 22:3, 323-325.

Batan N. Alataş M. Erata H. Özdemir T. 2019. Two remarkable moss species new to Turkey and South-west Asia. Plant Biosystems. 153:2, 195-198.

Cortini-Pedrotti C. 2001. Flora dei muschi d'Italia. Sphagnosida, Andreaeopsida, Bryopsida (I parte). Antonio Delfino Editore. Roma.

Cortini-Pedrotti C. 2006. Flora dei muschi d'Italia, Bryopsida (II parte). Roma: Antonia Delfino Editorea.

Erata H. Özen Ö. Batan N. Özdemir T. 2017. Karadeniz Teknik Üniversitesi Kanuni Kampüsü Briyofit Florası. Anatolian Bryology. 3:1, 9-18.

Erata H. Batan N. 2020. New and remarkable bryophyte records from Turkey and SouthWest Asia. Plant Biosystems. 154, 376-383.

Erdağ A. Kürschner H. 2017. Türkiye Bitkileri Listesi (Karayosunları). Ali Nihat Gökyiğit Vakfi Yayını. İstanbul.

Ezer T. 2016. Fissidens gymnandrus (Bryophyta, Fissidentaceae), a new moss record from Turkey and Southwest Asia. Phytologia Balcanica. 22:1, 3-5.

Greven H.C. 1995. Grimmia Hedw. (Grimmiaceae, Musci) in Europe. Backhuys Publishers, Leiden, The Netherlands.

Greven H.C. 2003. Grimmias of the World. Backhuys Publishers. Leiden.

Halıcı M.G. Akata I. 2020. Lichenized Fungi determined in Ankara University Beşevler 10. Yil Campus Area (Ankara-Turkey), 3rd International Eurasian Conference on Biological and Chemical Sciences (EurasianBioChem 2020), March 19-20, 2020 Ankara, Turkey.

Henderson D.M. 1961. Contributions to the bryophyte flora of Turkey: IV. - Notes from the Royal Botanic Garden, Edinburgh. 23, 263-278.

Heyn C.C. Herrnstadt I. 2004. The Bryophyte Flora of Israel and Adjacent Regions. The Israel Academy of Science and Humanities Jerusalem. Israel.

Hodgetts N.G. Söderström L. Blockeel T.L. Caspari S. Ignatov M.S. Konstantinova N.A. Lockhart N. Papp B. Schröck C. Sim-Sim M. et al. 2020. An annotated checklist of 
bryophytes of Europe, Macaronesia, and Cyprus. Journal of Bryology. 42:1, 1-116.

Kürschner H. Frey W. 2020. Liverworts, Mosses and Hornworts of Southwest Asia (Marchantiophyta, Bryophyta, Anthocerotophyta). Nova Hedwigia, 149. $267 \mathrm{p}$.

Munoz J. 1999. A Revision of Grimmia (Musci, Grimmiaceae) in The Americas, 1: Latin America. Annals of the Missouri Botanical Garden, 86. pp: 118-191.

Özdemir T. Batan N. 2014. New and noteworthy moss records for Turkey and Southwest Asia. Telopea. 17, 35-42.

Ros R.M. Mazimpaka V. Abou-Salama U. Aleffi M. Blockeel T.L. Brugués M. Cros R.M. Dia M.G. Dirkse G. Draper I. et al. 2013. Mosses of the Mediterranean, an annotated checklist. Cryptogamie Bryologie. 34, 99-283.

Sabovljevic M. Grdovic S. 2009. Bryophyte Diversity Within Urban Areas: Case Study of the City of Belgrade (Serbia). International Journal of Botany. 15:1, 85-92.

Smith A.J.E. 2004. The Moss Flora of Britain and Ireland. (Second Edition) Cambridge University Press. Cambridge.

Ursavaş S. Işın Z. 2019. New Records of Bryum gemmiferum and Atrichum crispum for Turkey. Plant Biosystems. 153:5, 686-690.

Yücel E. Ezer T. 2018. The Bryophyte Flora of Eskişehir Province (Turkey). Arctoa. 27:2, 164-171.

Zander R.H. 1993. Genera of The Pottiaceae: Mosses of Harsh Environments. Bulletin of the Buffalo Society of Naturel Sciences 32. Newyork. 